\title{
A RESPONSABILIDADE CIVIL DO ENTE ESTATAL PELO MANEJO INDEVIDO DE RECURSOS HÍDRICOS
}

\author{
THE LIABILITY OF ENTITY STATE BY IMPROPER HANDLING OF WATER \\ RESOURCES
}

\begin{abstract}
Carolina Miranda do Prado Mascarenhas
Mestranda em Direito Ambiental e Desenvolvimento Sustentável pela Escola Superior Dom Helder Câmara. Especialista em Advocacia Trabalhista pela Escola Superior de Advocacia da OAB/MG. Especialista em Direito Civil pelo Instituto de Educação Continuada da PUC-Minas. Bacharel em Direito pela Escola Superior Dom Helder Câmara. Advogada. E-mail: carolina.mascarenhas@yahoo.com.br
\end{abstract}

Denise Sousa Campos

Graduada em Direito pela Pontifícia Universidade Católica de Minas Gerais; Pós-graduada em Direito do Trabalho e Processo Trabalho pela Pontifícia Universidade Católica de Minas Gerais, Discente do programa de Mestrado em Direito Ambiental e Desenvolvimento Sustentável da Escola Superior Dom Helder Câmara e Membro da

Ordem dos Advogados de Minas Gerais. E-mail: fisiodireito2007@hotmail.com

Elcio Nacur Rezende

Doutor e Mestre em Direito. Professor do Programa de Pós-graduação em Direito da Escola Superior Dom Helder Câmara. E-mail: elcionrezende@yahoo.com.br

Recebido em: 14/06/2016

Aprovado em: 24/07/2016

Doi: $10.5585 /$ rdb.v15i6.403

RESUMO: A consagração do meio ambiente como um direito fundamental se revela diante da premissa de que a todos é garantido um meio ambiente ecologicamente equilibrado, sendo dever do Estado tomar medidas em prol de gerar mecanismos em busca desta garantia. Um dos componentes que compõem o meio ambiente são os recursos hídricos, essenciais à vida humana, finitos e com valor econômico, devendo ser dispendida atenção especial ao seu manejo. Aquele que causar danos às águas, incluindo-se aqui a figura do Estado, deve ser responsabilizado civilmente, pautado no ideário objetivo sem necessidade de comprovação de dolo ou culpa.

Palavras-chave: Recursos Hídricos. Responsabilidade civil objetiva. Responsabilidade civil do Estado.

ABSTRACT: The Consecration of the environment as a fundamental right is revealed on the premise that everyone is guaranteed an ecologically balanced environment, and the state should take measures in favor of generating mechanisms in search of this guarantee. One of the 
components that make up the environment are water resources, essential to human, finite and economic value life and must be expended particular attention to their management. One who cause damage to water, including here the state figure, should be held accountable civilly, based on objective ideas without proof of intent or guilt.

Keywords: Water resources. Objective liability. State.

SUMÁRIO: Introdução; 1. Da responsabilidade civil estatal; 1.1 A responsabilidade do Estado sob o viés do Direito pátrio; 2. Responsabilidade Civil por dano ambiental; 3. O Estado e os recursos hídricos; 4. O manejo indevido dos recursos hídricos pelo Estado; Considerações Finais; Referências.

\section{INTRODUÇÃO}

O mundo vivencia uma séria de catástrofes, em decorrência de um longo período de utilização dos recursos naturais por meio de ações antrópicas desregradas e inconsequentes, em prol da manutenção de uma ordem consumista e uma falácia de bem-estar pautado no capitalismo desenfreado.

A sociedade mundial já vem sentindo as consequências que tais atitudes desregradas vêm causando ao meio ambiente e, dessa forma, busca reverter os danos ambientais através da evolução de normas pautadas nos princípios da preservação, precaução e solidariedade.

Não foi diferente com o ordenamento jurídico pátrio que acabou aderindo ao texto constitucional mecanismos em prol da garantia da dignidade humana, dentre eles a garantia de um meio ambiente ecologicamente equilibrado como requisito essencial à sobrevivência humana.

O meio ambiente é dotado de um complexo de elementos interligados que possui como um de seus elementos os recursos hídricos, essenciais à manutenção da vida, dotado de valor econômico, e ainda, recurso finito, devendo ser criadas políticas públicas em prol de sua utilização sustentável e consciente.

Dentre um dos mecanismos criados em prol da tutela ambiental, têm-se os parâmetros da responsabilidade civil dos agentes causadores de danos ao meio ambiente, que conforme ficou consagrado na legislação pátria, será objetiva, dispensando a comprovação de dolo ou culpa do causador do dano.

Até mesmo pela complexidade e abrangência que os danos causados contra os recursos hídricos que, de forma escalonada, acaba por afetar os demais componentes do meio ambiente, é que deve ser imposto ao Estado o investimento em sistemas preventivos e de precaução.

E assim, torna-se imprescindível indagar se o Estado deve responder civilmente por danos ambientais causados em virtude do manejo indevido dos recursos hídricos.

$\mathrm{Na}$ busca de uma efetiva tutela ao meio ambiente, o presente estudo irá abordar uma nova hermenêutica jurídica ambiental, em que se atribui a responsabilidade civil objetiva ao ente estatal pelo manejo indevido dos recursos hídricos em decorrência das suas ações ou omissões, que se confirma pela aplicação da teoria do risco integral em virtude das garantias consagradas constitucionalmente.

Para a resolução da problemática apresentada, será feita uma análise do fenômeno jurídico da responsabilidade civil estatal por danos causados aos recursos hídricos, em um viés tridimensional, composto pela situação fática, axiológica e normativa, com a utilização da vertente metodológica dogmática-jurídica, desenvolvendo raciocínios críticos com vistas à compreensão dos institutos normativos existentes aplicados em prol da tutela ambiental. 


\section{DA RESPONSABILIDADE CIVIL ESTATAL}

A responsabilidade atribuída ao ente estatal, correspondendo à obrigação legal de reparação de danos causados a terceiros, abrange os atos ilícitos, não se incluindo neste rol a atividade legítima exercida pelo Poder Público, embora a responsabilidade, segundo Cahali (2007, p. 13) "desfrute de maior amplitude, para compreender também os danos injustos causados por uma atividade lícita da Administração”.

A partir dessa breve análise, é importante ainda traçar seu escorço histórico para se verificar a sua origem e evolução, buscando um melhor entendimento sobre essa construção ao longo dos tempos até se chegar no atual entendimento da responsabilidade civil estatal.

De tal modo, rememorando a Idade Contemporânea, percebe-se uma ausência de responsabilização do ente estatal por seus atos que causavam danos ao cidadão, diante da predominância da teoria do direito divino (RIZZARDO, 2006, p. 355).

Assim, Rizzardo melhor explicita:

Especialmente quando dominava o absolutismo dos reis e o despotismo, os atos dos soberanos ou tiranos e de seus agentes não eram questionados. Os monarcas consideravam-se acima da lei, sendo que, em alguns regimes, tinham o poder sobre a própria vida e os bens dos súditos, vigorando uma isonomia de restrições absoluta, revelada em expressões como a seguinte, L'État c' est moi (o Estado sou eu). Os déspotas, embora o desenvolvimento trazido em seus governos, não se submetiam a qualquer controle. (RIZZARDO, 2006, p. 355)

Conforme se depreende, nos Estados despóticos ou absolutos vigorava a ausência de qualquer vestígio de responsabilidade em favor de seus súditos, em virtude deste absolutismo que carregava esse axioma de irresponsabilidade, uma vez que era inquestionável a legitimidade do Estado.

Caracterizava-se assim a Teoria da irresponsabilidade estatal, pois a possibilidade de uma condenação pecuniária advinda do erário ante um evento danoso, considerar-se-ia como um verdadeiro obstáculo à liberdade dos serviços.

$\mathrm{Na}$ concepção de Cahali, a Teoria da irresponsabilidade absoluta da Administração Pública tem sua base de sustentação concretizada diante de três postulados:

1) Na soberania do Estado, que, por natureza irredutível, proíbe ou nega sua igualdade ao súdito, em qualquer nível de relação; a responsabilidade do soberano perante o súdito é impossível de ser reconhecida, pois envolveria uma contradição nos termos da equação; 2) segue-se que, representando o Estado soberano o direito organizado, não pode aparecer como violador desse mesmo direito; 3) daí, os atos contrários à lei praticados pelos funcionários jamais podem ser considerados atos do Estado, devendo ser atribuídos pessoalmente àqueles, como praticados nomine próprio. (CAHALI, 2007, p. 21)

Dentro desta concepção de irresponsabilidade estatal, abstrai-se que o Estado gozava de uma imunidade absoluta, não existindo a possibilidade de constituir direitos contra este e nem de se exigir reparação por erros cometidos em nome do Estado.

Ainda, Alexandrino e Paulo (2006, p. 474) afirmam que os "agentes públicos, como representantes do próprio rei, não poderiam [...] ser responsabilizados por seus atos, ou melhor, seus atos na qualidade de atos do rei, não poderiam ser considerados lesivos aos súditos”. 
Nesta concepção, observa-se que a teoria da irresponsabilidade decorria do próprio conceito de soberania em que se defendia a ideia de que se era o Estado (representado pelo rei) quem exercia a tutela do Direito, ele jamais poderia violá-lo.

Esta teoria não representou raízes para o atual entendimento da responsabilidade civil do Estado, servindo tão somente para fins meramente históricos e porquanto evolutivo do Direito, não sendo adotada atualmente por nenhum país.

Nesse sentido, Di Pietro assevera:

Essa teoria logo começou a ser combatida, por sua evidente injustiça; se o Estado deve tutelar o direito, não pode deixar de responder quando, por sua ação ou omissão, causar danos a terceiros, mesmo porque, sendo pessoa jurídica, é titular de direitos e obrigações. (DI PIETRO, 2011, p. 644)

A própria doutrina passou a trazer questionamentos referentes a esse modelo que a teoria da irresponsabilidade não era capaz de responder, nascendo a certeza de que a mudança se fazia necessária.

Sobre o tema Cahali destaca:

Na doutrina, pôs-se em evidência que a teoria da irresponsabilidade representava clamorosa injustiça, resolvendo-se na própria negação do direito: se o Estado se constitui para a tutela do direito, não tinha sentido que ele próprio o violasse impunemente; o Estado, como sujeito dotado de personalidade, é capaz de direitos e obrigações como os demais entes, nada justificando a sua responsabilidade. (CAHALI, 2007, p. 21-22)

Esta insatisfação restou claramente evidenciada com a Revolução Francesa, que buscou impor "freios ao poder absoluto, passando as comunas a responder pelos desmandos das forças policiais, o que se propagou em outros países". Nascia assim a responsabilidade do Estado, sendo que a França sediou os pioneiros movimentos nesse sentido. (RIZZARDO, 2006, p. 355)

Ultrapassada as noções sobre a não responsabilização estatal, é importante apresentar a evolução da responsabilidade estatal fundada na culpa, mas ainda diferenciada com relação à sua aplicação.

Inicialmente distinguiam-se para fins de responsabilidade do ente estatal os atos de império e os atos de gestão. Neste sentido, entendiam-se como atos de império aqueles em que o ente estatal atuava com suas prerrogativas de autoridade e de supremacia sobre os particulares, permanecendo a característica de poder soberano, já os denominados atos de gestão, eram caracterizados por aqueles praticados pelo Poder Público em situação de igualdade com os particulares, na administração do patrimônio ou dos serviços do Estado. (DI PIETRO, 2011, p. 644)

Diante desta divisão pré-estabelecida, presenciava-se a aplicabilidade da responsabilidade civil direcionada aos danos ocorridos em virtude tão somente dos atos de gestão.

Outrossim, Cahali aponta:

Agindo o Estado no exercício de sua soberania, na qualidade de poder supremo, supra-individual, os atos praticados nessa qualidade, atos jure imperii, restariam incólumes a qualquer julgamento e, mesmo quando danosos para os súditos, seriam insuscetíveis de gerar direito à reparação. Todavia, na prática de atos jures gestionis, o Estado equipara-se ao particular, podendo ter sua responsabilidade civil reconhecida, nas mesmas condições de uma empresa 
privada, pelos atos de seus representantes ou prepostos lesivos ao direito de terceiros; distinguia-se, então, conforme tivesse havido ou não culpa do funcionário: havendo culpa, a indenização seria devida; sem culpa, não haveria ressarcimento do dano. (CAHALI, 2007, p. 22-23)

A partir dessa perspectiva, observava-se o início da Teoria da responsabilidade com culpa civil comum do Estado, com caráter meramente subjetivo, uma vez que a obrigação de reparar o dano somente era exigida diante da comprovação do dolo ou culpa dos atos praticados pelos agentes do Estado.

Foi no fim da Idade Moderna que se concretizaram os princípios esparsos da responsabilidade do Estado por determinados atos, com base no ideário subjetivista, ou seja, na presença de culpa ou dolo, consolidando-se formalmente, somente em meados do século XIX até a metade do século XX.

Assim, os atos causados pelos agentes do Estado que geravam danos a terceiros, desde que ficassem devidamente comprovados pelo ofendido ou quem tivesse legitimidade de representá-lo juntamente com a comprovação de culpa ou dolo eram passíveis de reparação.

Ocorre que mesmo com a teoria da responsabilidade civil do Estado subjetiva em que necessitava da comprovação da culpa ou dolo do agente do Estado, chegou num momento que também não mais respondia aos anseios pleiteados.

Sustenta Cahali (2007, p. 24) que essa inadequação da teoria pautada no pressuposto culpa não tinha características suficientes para "explicar o dano que traria resultado de falha da máquina administrativa, de culpa anônima da Administração, buscando-se então, supri-la através da concepção de culpa publicística".

Com isso, passa a ser admitida a responsabilidade do Estado caracterizada em virtude da omissão da Administração. Surgia então, a culpa presumida para a responsabilização do ente estatal que diante da omissão da prestação de serviços ou da prestação intempestiva gerava danos aos administrados.

Essa caracterização da culpa presumida também pode ser verificada nos ensinos de Cavalieri Filho:

Convém, ainda, registrar que em inúmeros casos de responsabilidade pela falta do serviço admite-se a presunção de culpa em face da extrema dificuldade, às vezes instransponível, de se demonstrar que o serviço operou abaixo dos padrões devidos, casos em que se transfere para o Estado o ônus de provar que o serviço funcionou regularmente, de forma normal e correta, sem o que não conseguirá elidir a presunção e afastar a sua responsabilidade. (CAVALIERI FILHO, 2006, p. 251)

Contudo, tendo em vista a posição ocupada pelo ente estatal perante seus administrados, a teoria da responsabilidade civil subjetiva, mesmo com a possibilidade de responsabilização pela culpa presumida, já não mais atendia veementemente os anseios, razão pelo qual se evoluiu para a responsabilidade objetiva.

Destaca-se que a responsabilidade civil do Estado que teve sua matriz civilista passa a ser inserida no campo do Direito Público, caracterizando assim, a terceira e última fase evolutiva do referido instituto.

Sustenta Rizzardo (2006, p. 356) que "por último, surgiu e se firmou a teoria da responsabilidade objetiva, que conduz a obrigar o Estado a indenizar o dano independente de culpa". 
O fundamento que permeia a responsabilidade objetiva estatal se caracteriza pelo fato de que o Estado, quando da prática de seus atos em prol da promoção do bem-social, pode, involuntariamente, gerar danos a pessoas, devendo nessa seara indenizar a vítima.

Contudo há uma exceção à regra imposta, retirando do Estado a obrigatoriedade de reparar o dano que se dá diante da comprovação de que a vítima concorreu com culpa ou dolo para caracterização do evento danoso, competindo ao ente estatal comprovar a culpa da vítima.

A doutrina apresenta no campo da responsabilidade objetiva do Estado, a denominada teoria do risco administrativo que encontra respaldo na teoria do risco integral, como se passa a analisar.

Sobre a teoria do risco administrativo, afirma-se que essa surgiu diante dos ideários propostos por Léon Duguit e desenvolvida por demais teóricos, chegando ao seguinte conceito: "A administração pública gera risco para os administrados, entendendo-se como tal a possibilidade de dano que os membros da comunidade podem sofrer em decorrência da normal ou anormal atividade do Estado". (CAVALIERI FILHO, 2006, p. 252)

Essa teoria fundamenta-se consoante a própria conceituação que carrega em si o ente estatal, visto como representante de todos os membros sociais, tem o dever de sustentar, porquanto suportar os ônus da atividade exercida sem qualquer dependência da culpa dos seus agentes.

Em termos gerais, a teoria do risco administrativo configura-se diante da atividade exercida pelo Estado e o consequente risco inerente a esse exercício que é capaz de configurar a sua responsabilização.

Pertinente apresentar os ensinamentos de Cavalieri Filho:

Esta teoria como se vê, surge como expressão concreta do princípio da igualdade dos indivíduos diante dos encargos públicos. É a forma democrática de repartir os ônus e encargos sociais por todos aqueles que são beneficiados pela Atividade da Administração Pública. Toda lesão sofrida pelo particular deve ser ressarcida, independentemente de culpa do agente público que a causou. O que se tem que verificar é, apenas, a relação de causalidade entre a ação administrativa e o dano sofrido pelo administrado. (CAVALIERI FILHO, 2006, p. 253)

Consoante se depreende das ponderações aventadas, a base da fundamentação da teoria do risco administrativo se enraíza no princípio da igualdade e no paradigma democrático de partilhar entre os beneficiários da atividade do ente estatal os ônus e encargos sociais.

Pautada no ideário da objetividade da responsabilidade civil estatal, o fator comprovação da culpa é elemento prescindível para fins de responsabilização do Estado, que por sua vez carrega o direito de afastá-la diante da confirmação de exclusão do nexo causal, tendo como fundamentos a culpa exclusiva da vítima, caso fortuito ou de força maior ou mesmo fato exclusivo de terceiro.

Logicamente, diante deste afastamento do nexo causal, é que se consolida a assertiva de que mesmo a responsabilidade do Estado pautada nos ideários da teoria do risco administrativo, não carrega consigo o insofismável caráter de absolutividade em casos de danos suportados por seus administrados.

Corroborando com a assertiva, Cavalieri Filho (2006, p. 253) aduz que "se o Estado, por seus agentes, não deu causa a esse dano, se inexiste relação de causa e efeito entre a atividade administrativa e a lesão, não terá lugar a aplicação da teoria do risco administrativo, e por via de consequência, o Poder Público não poderá ser responsabilizado".

Paralelamente a teoria do risco administrativo verifica-se a denominada teoria do risco integral que conforme Cahali (2006, p. 38) pode ser definida da seguinte forma: "a teoria do risco 
integral é a modalidade extremada da doutrina do risco administrativo, abandonada na prática, por conduzir ao abuso e à iniquidade social". O doutrinador ainda complementa: "por essa fórmula radical, a Administração ficaria obrigada a indenizar todo e qualquer dano suportado por terceiros, ainda que resultante de culpa ou dolo da vítima".

Pela teoria do risco integral, não pode o Estado valer-se do direito de invocar o afastamento de sua responsabilidade pela exclusão do nexo causal, como ocorre na teoria do risco administrativo, sendo obrigado a indenizar todo e qualquer dano causado ao particular.

Outrossim Rizzardo (2006, p. 356) aduz que "qualquer fato que importe em lesão aos interesses, desde que dentro da esfera de serviços prestados pelo Estado, constitui razão para se buscar a reparação".

E por sua vez, Cahali assinala:

Com efeito, a distinção entre risco administrativo e risco integral não é ali estabelecida em função de uma distinção conceitual ou ontológica entre as duas modalidades pretendidas de risco, mas simplesmente em função das consequências irrogadas a uma ou outra modalidade: o risco administrativo é qualificado pelo seu efeito de permitir a contraprova de excludente de responsabilidade, efeito que se pretende seria inadmissível se qualificado como risco integral, sem que nada seja enunciado quanto à base ou natureza da distinção. (CAHALI, 2006, p. 40)

Feitas tais ponderações sobre a evolução da responsabilidade civil do ente estatal, necessário, porquanto primordial, trazer uma análise relativa a aplicabilidade deste instituto pelo viés do ordenamento jurídico pátrio.

\subsection{A responsabilidade do Estado sob o viés do Direito pátrio}

Como abordado anteriormente, a responsabilidade civil em seu escorço histórico se fundamentava inicialmente na teoria da irresponsabilidade, fase não vivenciada pelo Brasil, uma vez que "mesmo à falta de disposição legal específica, a tese de responsabilidade do Poder Público sempre foi aceita como princípio geral e fundamental do Direito". (CAVALIERI FILHO, 2006, p. 254)

Rememorando o texto constitucional de 1824, Constituição Política do Império do Brasil, em seu art. 178, XXIX, preceituava que "os Empregados Públicos são estritamente responsáveis pelos abusos, e omissões praticadas no exercício das suas funções, e por não fazerem efetivamente responsáveis aos seus subalternos". (BRASIL, 1824)

Consoante se observa nas entrelinhas do preceito constitucional retro citado, a responsabilidade civil do Estado era fundada na culpa e dirigia a responsabilidade aos agentes da administração diante de atos exercidos com negligência, imprudência ou imperícia.

Ato contínuo, "a primeira Constituição da República, de 1891 manteve regra igual no art. 79”. (RIZZARDO, 2006, p. 357)

No âmbito do Direito Civil, é possível constatar que o Código Civil de 1916 constituiu o primeiro diploma legislativo a abordar de maneira específica a responsabilidade civil do Estado, consoante se depreende do art. 15, in verbis:

As pessoas jurídicas de direito publico são civilmente responsáveis por atos dos seus representantes que nessa qualidade causem danos a terceiros, procedendo de modo contrario ao direito ou faltando a dever prescrito por lei, salvo o direito regressivo contra os causadores do dano. (BRASIL, 1916) 
Analisando referido preceito jurídico, a responsabilidade atribuída às pessoas jurídicas de direito público possui como pressuposto para a responsabilização o fator culpa, embora inicialmente tal dispositivo ter sido considerado ambíguo.

Diante da sustentada tese da ambiguidade e contradição do art. 15 do Código Civil de 1916, alguns teóricos como Rui Barbosa, Pedro Lessa utilizaram-se dela para iniciar uma discussão acerca da responsabilidade objetiva do Estado, tendo como influência diplomas internacionais, tais como os existentes em alguns países europeus, como a França. (CAVALIERI FILHO, 2006, p. 255)

Consoante pode ser percebido, a evolução da responsabilidade civil estatal nasceu primeiramente da hermenêutica de um preceito civilista, sendo consolidada pelo ordenamento constitucional de 1946, art. $194^{2}$.

Ainda, Cavalieri Filho destacou:

Uma vez entronizada no texto constitucional brasileiro, a responsabilidade objetiva do Estado de lá não mais foi retirada. Até mesmo nas Constituições de 1967 e de 1969, outorgadas pelo regime militar autoritário, foi ela mantida nos arts. 105 e 107, respectivamente, nos mesmos termos da Constituição de 1946. (CAVALIERI FILHO, 2006, p. 256)

Observar-se-á que a partir do ordenamento constitucional de 1946 adotou-se a aplicabilidade da responsabilidade civil estatal objetiva pautada no ideário do nexo de causalidade, afastando o pressuposto da culpa.

A Constituição Federal de 1988 (CF/88) apresentou preceitos relativos a responsabilidade objetiva estatal consoante preceitua art. $37, \S 6^{\circ}$ que dispõe que "as pessoas jurídicas de direito público e as de direito privado prestadoras de serviços públicos responderão pelos danos que seus agentes, nessa qualidade, causarem a terceiros, assegurado o direito de regresso contra o responsável nos casos de dolo ou culpa". (BRASIL, 1988)

Rizzardo (2006, p. 362) analisando o preceito constitucional explica que "a CF/88 adotou a chamada Teoria do Risco Administrativo - estendendo os seus efeitos às pessoas jurídicas de direito privado, empresas públicas, sociedades de economia mista, empresas permissionárias de serviços públicos".

De tal modo, para a responsabilização do ente estatal, com base na $\mathrm{CF} / 88$ basta a presença do nexo causal entre o dano e a ação ou omissão dos agentes da pessoa jurídica de direito público ou privado que prestam serviços públicos, sendo prescindível os requisitos comprobatórios de dolo ou culpa.

Outrossim, Pagel explica:

Portanto, de acordo com a responsabilidade objetiva, o Estado responde por seus atos independentemente de dolo ou culpa, sendo desconsiderados os elementos

\footnotetext{
${ }^{1}$ Cavalieri Filho assevera: "Não obstante a redação ambígua desse dispositivo, o que ensejou alguma controvérsia inicial, a melhor doutrina acabou firmando entendimento no sentido de ter sido, nele, consagrada a teoria da culpa como fundamento da responsabilidade civil do Estado. Tanto é assim que fala em representantes, ainda ligado à ideia de que o funcionário representaria o Estado, seria o seu preposto, tal como ocorre no Direito Privado. Ademais, as expressões "procedendo de modo contrário ao Direito ou faltando o dever prescrito por lei" não teriam sentido se não se referissem à culpa dos funcionários". (CAVALIERI FILHO, 2006, p. 255)

${ }^{2}$ Art 194 - As pessoas jurídicas de direito público interno são civilmente responsáveis pelos danos que os seus funcionários, nessa qualidade, causem a terceiros.

Parágrafo único - Caber-lhes-á ação regressiva contra os funcionários causadores do dano, quando tiver havido culpa destes. (BRASIL, 1946)
} 
subjetivos do caso concreto, bastando apenas, para sua responsabilização, a demonstração da existência de nexo de causalidade entre a conduta estatal e o dano causado, desde que não fique evidenciada a culpa exclusiva da vítima, caso fortuito ou força maior. (PAGEL, 2012, p. 241)

Consoante denota-se, regra geral, que a responsabilidade civil do ente estatal é objetiva, contudo imperioso afirmar que a responsabilidade civil estatal subjetiva não foi excluída do ordenamento pátrio e ainda prevalece em caráter excepcional. Como bem assevera Cavalieri Filho (2006, p. 277) a responsabilidade subjetiva se dará por "fatos de terceiros e fenômenos da natureza - determinando-se então, a responsabilidade da Administração, com base na culpa anônima ou falta de serviço, seja porque esta não funcionou, quando deveria normalmente funcionar, seja porque funcionou mal ou funcionou tardiamente".

Feitas tais ponderações, primordial trazer a análise da responsabilidade civil estatal por dano ambiental, mais incisivamente em decorrência do manejo indevido das águas, que será objeto de análise adiante.

\section{RESPONSABILIDADE CIVIL POR DANO AMBIENTAL}

A preocupação ambiental não é algo que remota a antiguidade, e só veio a tornar-se objeto de tutela diante da racionalização da ética e da consciência da importância do meio ambiente para a avida humana.

Segundo Barreira e Borges, abordam o princípio da responsabilidade pela teoria de Hans Jonas, ressaltando a ética e o meio ambiente, consoante denota-se:

A busca pela ética através da responsabilidade individual para uma civilização tecnológica foi um dos grandes momentos da passagem filosófica de Hans Jonas. Por isso, em 1979, o filósofo publica sua principal obra: O princípio da responsabilidade. Ensaio de uma técnica para civilização tecnológica, que propõe uma ética que a todos responsabiliza. Hans Jonas inova propondo uma nova ética, a ética com a natureza, reconstruindo a relação do homem tecnológico com o ambiente. A ética tradicional não atingia o ambiente. (BARREIRA, BORGES, 2014, p. 93)

Hodiernamente percebe-se o aumento da preocupação de preservação ao meio ambiente em virtude de uma racionalidade humana que constata a necessidade de um meio ambiente equilibrado e saudável para manutenção de sua própria sobrevivência.

Essa preocupação advém logicamente da crise ambiental vivenciada pela destruição desenfreada dos recursos naturais pelo homem, que sempre os utilizou sem qualquer parâmetro de preservação ou precaução para a sua manutenção.

Consoante afirmam Moraes e Mol (2014, p. 185), "vemos a absoluta necessidade da solidariedade entre os homens, a responsabilidade ética e moral, a sensibilidade humana, habilidade de convívio, a tolerância e acima de tudo, mudança de hábitos".

Ademais, até mesmo a dignidade humana ${ }^{3}$, fundamento pátrio paradigmático do Estado Democrático de Direito, consagrado pela ordem constitucional, somente pode ser alcançada com

\footnotetext{
${ }^{3}$ Apresentando a importância da dignidade humana, Sarlet (2015, p. 78) aduz: "Consagrado expressamente, no título dos princípios fundamentais, a dignidade da pessoa humana como um dos fundamentos do nosso Estado Democrático (e social) de Direito (art. $1^{\circ}$, inc. III da CF), o nosso Constituinte de 1988 - a exemplo do que ocorreu, entre outros países, na Alemanha -, além de ter tomado uma decisão fundamental a respeito do sentido, da Revista de Direito Brasileira | São Paulo, SP | v. 15 | n. 6 | p. 239 - 254| set./dez. 2016
} 
a devida proteção do meio ambiente ecologicamente equilibrado, consoante explica Belchior (2011, p. 99) que "fala-se inclusive, em dimensão ecológica na dignidade humana, o que implica uma matriz fundante dos demais direitos fundamentais".

A propósito, Barreira e Borges (2014, p. 107) afirmam a possibilidade da finitude do planeta, devendo o homem preservar e protegê-lo, pois constitui direito das gerações futuras usufruí-lo, resultado assim a "necessidade de dar condições para que elas possam habitar este planeta de forma digna".

Entender a complexidade e a importância do positivismo de determinados contextos legislativos que se inter-relacionam para a consagração da dignidade humana, principalmente o direito ao meio ambiente ecologicamente equilibrado, é condição primordial para a construção de um paradigma estatal ambiental.

Cabe neste sentido ao Estado e a coletividade, o dever de proteger e preservar o meio ambiente ecologicamente equilibrado, por ser considerado ainda bem de uso comum do povo e essencial, porquanto necessário à sadia qualidade de vida, nos termos do art. 225 da Constituição Federal/1988. ${ }^{4}$

Traçado esse breve contexto, em que se nota que aquele que causa danos ao meio ambiente, inclusive o Poder Público, seja por meio da atuação da Administração Direta ou Indireta, fica obrigado a reparar, cessar o dano, e ainda, tentar reestabelecer o status quo ante.

Consoante a esse entendimento, Pagel preleciona:

[...] o Estado assume o risco de responder civilmente pelos danos ou degradação causados ao meio ambiente, nomeadamente porque é o principal responsável pela proteção e preservação de um ambiente ecologicamente equilibrado (Artigo 225 da CF/88 ). Logo, o ponto de partida para fundamentar a responsabilidade civil do Estado por danos causados ao meio ambiente passa a ser a própria Constituição Federal, porquanto se alargam as funções principiológicas e, principalmente, os valores protegidos constitucionalmente, tais como o bem social e a dignidade da pessoa humana. (PAGEL, 2012, p. 230)

Observa-se pelo descrito que, o ente estatal como um dos agentes que possuem como dever a proteção e a preservação de um meio ambiente ecologicamente equilibrado, atribuído por preceito constitucional, passa a ser também responsável civilmente pelos danos gerados.

Antes mesmo dessa consagração e elevação do meio ambiente ecologicamente equilibrado como direito fundamental como meio também de efetivação da dignidade humana, o ordenamento jurídico infraconstitucional já apresentava preceitos relativos à responsabilidade civil ambiental, podendo trazer como exemplificação o art. $14, \S 1^{\circ}$ da Lei $n^{\circ} 6.938 / 81$ in verbis:

Art $14-[\ldots]$

$\S 1^{\circ}$ - Sem obstar a aplicação das penalidades previstas neste artigo, é o poluidor obrigado, independentemente da existência de culpa, a indenizar ou reparar os danos causados ao meio ambiente e a terceiros, afetados por sua atividade. $\mathrm{O}$ Ministério Público da União e dos Estados terá legitimidade para propor ação de responsabilidade civil e criminal, por danos causados ao meio ambiente. (BRASIL, 1981)

finalidade e da justificação do exercício do poder estatal e do próprio Estado, reconheceu categoricamente que é o Estado que existe em função da pessoa humana, e não o contrário, já que o ser humano constitui a finalidade precípua, e não meio da atividade estatal."

${ }^{4}$ Art. 225. Todos têm direito ao meio ambiente ecologicamente equilibrado, bem de uso comum do povo e essencial à sadia qualidade de vida, impondo-se ao Poder Público e à coletividade o dever de defendê-lo e preservá- lo para as presentes e futuras gerações. (BRASIL, 1988) 
Da referida disposição denota-se a prevalência da responsabilidade civil objetiva diante de danos causados ao meio ambiente, ideário recepcionado pelo posterior texto constitucional, fundamentado na ideia central de que aquele quem cria o risco deve reparar os danos ocorridos em virtude da atividade prestada.

\section{O ESTADO E OS RECURSOS HÍDRICOS}

Tecidas as considerações acerca do instituto da responsabilidade civil do ente estatal, e mesmo ciente de que se realizou uma abordagem genérica e inevitavelmente incompleta, passa-se a analisar os recursos hídricos numa abordagem sistêmica do dever estatal com seu manejo.

O texto constitucional atribui competência à União, em seu art. 21, XIX, de "instituir sistema nacional de gerenciamento de recursos hídricos e definir critérios de outorga de direitos de seu uso", e ainda, competência comum da União, dos Estados, do Distrito Federal e dos Municípios, nos termos do art. 23, XI, de "registrar, acompanhar e fiscalizar as concessões de direitos de pesquisa e exploração de recursos hídricos e minerais em seus territórios". (BRASIL, 1988)

Objetivando atribuir eficácia ao ordenamento constitucional, em 1997 foi sancionada a Lei $n^{\circ} 9.433$ que "institui a Política Nacional de Recursos Hídricos, cria o Sistema Nacional de Gerenciamento de Recursos Hídricos, regulamenta o inciso XIX do art. 21 da Constituição Federal”. (BRASIL, 1997)

De fato, a Lei $\mathrm{n}^{\circ} 9.433$ trouxe regramentos em harmonia com a $\mathrm{CF} / 88$, principalmente diante do reconhecimento das águas como recurso natural limitado, bem de domínio público, entre outros:

Art. $1^{\circ}$ A Política Nacional de Recursos Hídricos baseia-se nos seguintes fundamentos:

I - a água é um bem de domínio público;

II - a água é um recurso natural limitado, dotado de valor econômico;

III - em situações de escassez, o uso prioritário dos recursos hídricos é o consumo humano e a dessedentação de animais;

IV - a gestão dos recursos hídricos deve sempre proporcionar o uso múltiplo das águas;

V - a bacia hidrográfica é a unidade territorial para implementação da Política Nacional de Recursos Hídricos e atuação do Sistema Nacional de Gerenciamento de Recursos Hídricos;

VI - a gestão dos recursos hídricos deve ser descentralizada e contar com a participação do Poder Público, dos usuários e das comunidades. (BRASIL, 1997)

Ainda em análise ao referido diploma, constata-se no art. $2^{\circ}$ o objetivo da Política Nacional de Recursos Hídricos, consoante segue:

Art. $2^{\circ}$ São objetivos da Política Nacional de Recursos Hídricos:

I - assegurar à atual e às futuras gerações a necessária disponibilidade de água, em padrões de qualidade adequados aos respectivos usos;

II - a utilização racional e integrada dos recursos hídricos, incluindo o transporte aquaviário, com vistas ao desenvolvimento sustentável; 
III - a prevenção e a defesa contra eventos hidrológicos críticos de origem natural ou decorrentes do uso inadequado dos recursos naturais. (BRASIL, 1997)

Tem-se clarividente a denotação de um diploma infraconstitucional que atribui preceitos em prol da utilização e do manejo dos recursos hídricos, na busca de um desenvolvimento sustentável.

Outrossim, Sarlet e Fensterseifer (2014, p. 254) afirmam que "a preocupação do legislador com os interesses das futuras gerações e também o delineamento de um desenvolvimento sustentável asseguram os contornos ecológicos de tal diploma legislativo [...]".

Em perfeita consonância com o texto constitucional (BRASIL, 1988), que afirma que "todos têm direito ao meio ambiente ecologicamente equilibrado, bem de uso comum do povo e essencial à sadia qualidade de vida, impondo-se ao Poder Público e à coletividade o dever de defendê-lo e preservá-lo para as presentes e futuras gerações”, a Lei nº 9.433/97 evidencia a preocupação com a qualidade das águas, como elemento integrador do meio ambiente e por conseguinte bem essencial à sobrevivência humana, e ainda a preocupação no combate aos danos que possam ser gerados aos recursos hídricos, reiterando-se sempre que o manejo destes devem ser direcionados ao bem coletivo e não a favor de interesses particulares.

Assim como é dever do este estatal em criar mecanismos de manejo correto dos recursos hídricos, inclui-se também sua responsabilidade fiscalizatória diante de concessões de serviços públicos, autorizações ou outorgas de direito de uso, sempre objetivando atingir a finalidade precípua dos preceitos legislativos, sejam eles constitucionais ou infraconstitucionais.

\section{O MANEJO INDEVIDO DOS RECURSOS HÍDRICOS PELO ESTADO}

A esta altura dos acontecimentos, principalmente diante da elevação do meio ambiente ecologicamente equilibrado a direito fundamental, consagração da dignidade humana, crise ambiental em decorrência de valores econômicos excessivos, entre outros, levaria a crer que a responsabilidade civil estatal frente ao manejo indevido dos recursos hídricos, incluindo-se aqui o dever fiscalizatório do Estado, deveria ser tema pacífico na doutrina dada tamanha magnitude e importância inclusive para a garantia da vida humana.

Contudo, não é assim que ocorre entre entendimentos despendidos na doutrina consoante será analisado.

A despeito do já mencionado art. 225 da $\mathrm{CF} / 88$, o seu $\S 3^{\circ}$ dispõe que "as condutas e atividades consideradas lesivas ao meio ambiente sujeitarão os infratores, pessoas físicas ou jurídicas, a sanções penais e administrativas, independentemente da obrigação de reparar os danos causados". (BRASIL, 1988)

Nesse sentido, "todo aquele que prejudica o equilíbrio atmosférico, aquático, a fauna, flora, topográfico, dentre outros elementos, quer no meio urbano ou rural deve, implacavelmente, responder juridicamente por sua ação ou omissão". (REZENDE, 2015, p. 511)

Obviamente que a obrigação de responsabilização pela ação ou omissão causadora de danos ao meio ambiente ecologicamente equilibrado estende-se ao Estado como representante da sociedade e em obediência aos preceitos legislativos.

Na lição de Rezende (2015, p. 514) "a Constituição Federal Brasileira e a Lei 6928/81 que estabelece a Política Nacional do Meio Ambiente não deixam dúvidas que em matéria ambiental dispensa-se a demonstração de dolo ou culpa na imputação daquele que degradou o Meio Ambiente". 
Contudo, consoante já abordado a Teoria do Risco Administrativo permite a alegação de excludentes de responsabilidade do ente estatal que por sua vez, não atende as emergências e efeitos escalonados que um dano ambiental gera.

Partindo-se da proporcionalidade e razoabilidade na aplicabilidade da imputação de responsabilidade civil ao ente estatal por dano ambiental, Rezende apresenta:

Parte da doutrina brasileira afirma que somente com a adoção da Teoria do Risco Integral o meio ambiente estará efetivamente protegido, uma vez que aquele que degradou o meio ambiente sempre será responsabilizado, ainda que comprove o fortuito, força maior, culpa exclusiva da vítima ou de terceiro. (REZENDE, 2015, p. 514)

Como um complexo interligado, o meio ambiente é constituído por um sistema multifatorial inseparável, onde a demora na tomada de atitudes diante de um dano pode, por via de consequência, ser irreparável, pois ao se permitir essa demora é o mesmo que silenciar para a continuidade, a qualquer custo, da utilização dos recursos naturais incluindo os hídricos sem quaisquer critérios de preservação e precaução. E com isso, não se pode afastar dessas mesmas disposições o ente estatal, responsável pela proteção do meio ambiente ecologicamente equilibrado como bem essencial à sadia qualidade de vida, que seja por sua ação, ou mesmo por sua omissão poderá ser responsabilizado.

A propósito, Rezende afirma:

Conclui-se, pois, que são sérias as discussões sobre a Responsabilidade Civil Ambiental, pois não se deseja jamais que haja qualquer dificuldade em se imputar o dever de reparar e/ou indenizar a quem degradou, nem tampouco, inexoravelmente, que se impute responsabilidade a quem não tem qualquer comportamento que em tese provocou ou poderia evitar determinado dano ambiental. (REZENDE, 2015, p. 515)

Assim, em que pese a adoção da responsabilidade civil objetiva pautada na Teoria do Risco Administrativo, a tutela ao meio ambiente, efetivamente reconhecido pela sua extremada importância à sobrevivência humana, e ainda, diante dos princípios da prevenção, reparação e precaução, quando se trata de dano ambiental, não deveria ser afastada pelas alegações de excludentes de nexo causal, adotando-se nestas situações a Teoria do Risco Integral, atribuindo-a também ao Estado.

Gonçalves (2012, p. 106) aduz que "é irrelevante a demonstração do caso fortuito ou da força maior como excludentes da responsabilidade civil por dano ecológico", motivo pelo qual estas não poderão ser invocadas pelo este estatal para afastar sua responsabilidade civil pelo manejo errôneo das águas.

Logo, não há outra conclusão a não ser que o manejo errôneo dos recursos hídricos pelo ente estatal, aqui subentendidas como suas ações ou mesmo omissões, deverão atribuir responsabilidade de reparação do ente, diante de danos causados ao meio ambiente dotado de valores indisponíveis ambientais constitucionais.

Assim tem-se a jurisprudência pátria:

Ambiental e administrativo. Ação civil pública. Tratamento sanitário de esgoto. Inexistência. Poluição do curso d'água que abastece o município de rio branco/ac. Lançamento de efluentes líquidos in natura no rio acre. Dano ambiental e à saúde pública. Competência comum dos entes federados. Serviço de água e esgoto de rio branco - SAERB. Responsabilidade. União e FUNASA. Cooperação técnica e financeira. Intervenção do poder judiciário em tema de 
implementação de políticas públicas. Legitimidade. Imposição de multa cominatória diária contra o poder público. Obrigação de fazer. Art. 461 do cpc. Possibilidade. 1. O art. 225 da Constituição de 1988 erigiu o meio ambiente ecologicamente equilibrado a "bem de uso comum do povo e essencial à sadia qualidade de vida" - expressão que abrange a saúde, o bem estar e a segurança da população -, reconhecendo, desse modo, a sua natureza de bem difuso, de direito público subjetivo e, pois, "exigível e exercitável em face do próprio Estado", a quem incumbe, assim como à coletividade, o dever de protegê-lo. De resto, é na proteção à saúde humana que reside, historicamente, o fundamento primeiro para a tutela ambiental (Édis Milaré in "Direito do Ambiente", Editora Revista dos Tribunais, São Paulo, $5^{a}$ edição, p. 142). Dessa estreita relação entre meio ambiente e saúde resulta que um meio ambiente saudável é indispensável a uma existência salubre. 2. Demonstrado, no caso dos autos, que as águas de um dos principais rios que abastece o Município de Rio Branco apresentam altíssimos índices de poluição devido ao lançamento, no seu leito, de efluentes líquidos in natura - já que inexiste adequado tratamento sanitário do esgoto municipal -, comprometendo sobremaneira a saúde da população local, não há como possa ser excluída a responsabilidade da pessoa jurídica de direito público municipal encarregada da exploração dos serviços de água e esgoto locais, qual seja, o Serviço de Água e Esgoto de Rio Branco - SAERB pelo referido dano ambiental. [...] (ACRE. Tribunal Regional Federal, $1^{\text {a }}$ Região. Processo ${ }^{\mathrm{o}}$ : AC 0000494-76.2004.4.01.3000, Relator: Desembargadora Selene Maria de Almeida. Diário Eletrônico da Justiça Federal: p.132. 27/08/2010)

Ademais a titularidade da indenização, no caso de danos ambientais, é caracterizada pela coletividade, consoante já visto mais primordial reiterar, principalmente pela magnitude da importância do meio ambiente ecologicamente equilibrado para atingir a finalidade primordial do Estado Democrático de Direito estampado no paradigma da consagração da dignidade humana.

\section{CONSIDERAÇÕES FINAIS}

A tutela ambiental é dever da coletividade e do ente estatal que, como representante máximo da sociedade, tem por obrigação gerar mecanismos em prol da garantia do meio ambiente ecologicamente equilibrado, incluindo o manejo sustentável, consciente e correto das águas, criando políticas sociais e econômicas almejando a preservação dos recursos hídricos, vez que fonte esgotável, dotada de valor econômico, sendo ainda considerada essencial à manutenção humana.

Contudo, quando o ente estatal por meio de ato comissivo ou omissivo gera danos aos recursos hídricos em decorrência do seu manejo indevido, surge assim, o dever da responsabilização civil do Estado.

No decorrer da evolução do instituto da responsabilidade civil estatal, constata-se a migração da responsabilidade civil subjetiva para a responsabilidade civil objetiva. E foi verificado que ambos ideários de responsabilização civil ainda possuem aplicabilidade no ordenamento jurídico pátrio.

Ademais, vislumbra-se ainda a presença da teoria do risco administrativo, onde o Estado, como instrumento para afastar ou minimizar sua responsabilização pode comprovar as excludentes de responsabilidade, assim consideradas como caso fortuito, força maior, culpa exclusiva da vítima ou de terceiros, e, lado outro, a teoria do risco integral, onde a administração é responsabilizada civilmente sem a possibilidade de arguição das referidas excludentes, sendo em ambos os casos dispensável o elemento culpa ou dolo. 
Ocorre que o dano ambiental necessita de resposta imediata, na mesma medida e celeridade dos estragos que podem atingir dimensões que fogem ao alcance humano de correção e reparação.

Em virtude deste emergencial caráter reparatório do ente estatal diante do manejo indevido dos recursos hídricos, observa-se que a adoção da teoria do risco integral frente ao dano ambiental seria medida imposta às necessidades prementes.

$\mathrm{O}$ direito fundamental ao meio ambiente ecologicamente equilibrado como mecanismo de garantia à dignidade humana, representa um novo paradigma estatal pautado no Estado Democrático de Direito, não podendo admitir mitigação ou flexibilização da responsabilidade civil estatal por danos ao meio ambiente.

\section{REFERÊNCIAS}

ACRE. Tribunal Regional Federal, $1^{\mathrm{a}}$ Região. Processo $n^{o}$ : AC 0000494-76.2004.4.01.3000, Relator: Desembargadora Selene Maria de Almeida. Diário Eletrônico da Justiça Federal: p.132. 27/08/2010. Disponível em: < http://trf-1.jusbrasil.com.br/jurisprudencia/15981741/apelacaocivel-ac-494-ac-0000494-7620044013000> Acesso em: 01 jun. 2016.

ALEXANDRINO, Marcelo. PAULO, Vicente. Direito Administrativo. Rio de Janeiro: Impetus, 2006.

BARREIRA, Érika Campos. BORGES, Monike Valent Silva. Princípio da prevenção e a ética da responsabilidade de Hans Jonas na mineração brasileira. In: Entre a Filosofia e o Ambiente: bases filosóficas para o Direito Ambiental. Org. Émilien Villas Boas Reis. Belo Horizonte: $3 \mathrm{i}$ Editora, 2014. P. 93-115.

BELCHIOR, Germana Parente Neiva. Hermenêutica Jurídica Ambiental. São Paulo: Saraiva, 2011.

BRASIL. Constituição Política do Império do Brasil (1824). Manda observar a Constituição Politica do Império, oferecida e jurada por Sua Majestade o Imperador. Rio de Janeiro, 1824. Disponível em: <http://www.planalto.gov.br/ccivil_ 03/Constituicao /Constituicao24.htm> Acesso em: 21 abr. 2016.

BRASIL. Constituição dos Estados Unidos do Brasil (1946). Rio de Janeiro: Assembleia Constituinte, 1946. Disponível em: < http://www.planalto.gov.br/ccivil_03/ Constituicao/ Constituicao46.htm> Acesso em: 21 abr. 2016.

BRASIL. Constituição Federal (1988). Constituição da República Federativa do Brasil. Brasília: Senado, 1988.

BRASIL. Lei $n^{o}$ 3.071, de $1^{\circ}$ de janeiro de 1916. Código Civil dos Estados Unidos do Brasil. Rio de Janeiro: 1916. Disponível em: < http://www.planalto.gov.br/ccivil_03/leis/L3071.htm> Acesso em: 21 abr. 2016.

BRASIL. Lei $n^{\circ}$ 6.938, de 31 de agosto de 1981. Dispõe sobre a Política Nacional do Meio Ambiente, seus fins e mecanismos de formulação e aplicação, e dá outras providências. Brasília: 
1981. Disponível em: < http://www.planalto.gov.br/ccivil_03/leis/L6938.htm> Acesso em: 24 abr. 2016.

BRASIL. Lei $n^{o}$ 9.433, de 08 de janeiro de 1997. Institui a Política Nacional de Recursos Hídricos, cria o Sistema Nacional de Gerenciamento de Recursos Hídricos, regulamenta o inciso XIX do art. 21 da Constituição Federal, e altera o art. $1^{\circ}$ da Lei nº 8.001, de 13 de março de 1990, que modificou a Lei $\mathrm{n}^{\circ}$ 7.990, de 28 de dezembro de 1989. Brasília: 1997. Disponível em: < http://www.planalto.gov.br/ccivil_03/leis/L9433.htm> Acesso em: 25 abr. 2016.

CAHALI, Yussef Said. Responsabilidade Civil do Estado. São Paulo: Editora Revista dos Tribunais, 2007.

CAVALIERI FILHO, Sérgio. Programa de Responsabilidade Civil. São Paulo: Malheiros, 2006.

DI PIETRO, Maria Sylvia Zanella. Direito Administrativo. São Paulo: Atlas, 2011.

MORAES, Clarice Figueiredo de. MOL, Samylla. O consumo e meio ambiente na sociedade líquido-moderna de Bauman. In: Entre a Filosofia e o Ambiente: bases filosóficas para o Direito Ambiental. Org. Émilien Villas Boas Reis. Belo Horizonte: 3i Editora, 2014. P. 173-196.

PAGEL, Rogério. A responsabilidade civil do Estado frente à concessão de licença ambiental. Revista Veredas de Direito. V. 9, $\mathrm{n}^{\mathrm{o}} 18$ - p. 229-248. Jul/dez. 2012. Disponível em: <file://C:/Users/Bella.Daniel-PC/Downloads/293-1305-2-PB.pdf> Acesso em: 24 abr. 2016.

REZENDE, Elcio Nacur. Responsabilidade civil por danos ao meio ambiente urbano no direito constitucional, administrativo, civil e ambiental uma análise crítico-construtiva em prol de uma perquirição do degradador e de sua imputação. In: XXIV Congresso Nacional do CONPEDI. Direito urbanístico, cidade e alteridade. Coord: Edson Ricardo Saleme, Flavia Piva Almeida Leite, Daniel Gaio - Florianópolis: CONPEDI, 2015. p. 498 - 521. Disponível em: < http://www.conpedi.org.br/ publicacoes/66fs1345/mq42p84j/XB2T824eFcx1X863.pdf> Acesso em: 25 abr. 2016.

RIZZARDO, Arnaldo. Responsabilidade Civil. Rio de Janeiro: Forense, 2006.

SARLET, Ingo Wolfgang. Dignidade (da pessoa) humana e direitos fundamentais na Constituição Federal de 1988. Porto Alegre: Livraria do Advogado Editora, 2015.

SARLET, Ingo Wolfganf. FENSTERSEIFER, Tiago. Direito Ambiental: Introdução, Fundamentos e Teoria Geral. 